\title{
Stock Market Sensitivity to UK Firms' Pension Discounting Assumptions
}

Paper number 06/04

\author{
by \\ Paul J M Klumpes \\ Nottingham University Business School \\ University of Nottingham \\ Kevin McMeeking* \\ University of Exeter
}

\begin{abstract}
ABS TRACT
New UK pension accounting regulations significantly increase the exposure of the balance sheets of UK firms to volatilities in pension fund valuations. We examine whether the abnormal returns of firms that voluntarily used market based pension discount rates are significantly different from the abnormal returns of industrymatched pair samples of firms that retained traditional cost-based valuation assumptions during the period surrounding the release of the related exposure draft. We also examine the interest rate sensitivity of stock price returns over the four-year period before and after the announcement date. Consistent with our hypotheses, UK stock price returns incorp orate the effect of unexpected interest chan ges on sources of pension earnings for firms that voluntarily switched to market based assumptions, but do not incorp orate these effects for firms that do not switch. These results suggest that unexpected changes in interest rates have a differential effect on a firm's sources of pension, financial and core earnings.
\end{abstract}

\footnotetext{
*Contact Author: Kevin McMeeking, Lecturer in Accounting, School of Business and Economics, University of Exeter, Rennes Drive, Exeter EX4 4PU, Exeter, Devon, England. Tel: +44 1392263206 Email: K.P.McMeeking@exeter.ac.uk
} 
ISS N 14732904 


\section{INT RODUCTION}

UK pension accounting rules formerly required pension employers to recognize only the accrued or prepaid pension cost and usually defer and amortize any actuarial gains or losses. However, Financial Reporting Standard 17 (FRS17) requires full recognition of the excess pension deficit or surplus on the employer sponsors balance sheet and the immediate write-off of actuarial gains or losses. FRS17 is significantly different from the former UK GAAP requirements that pension gains or losses be smoothed over time. Assuming that markets are efficient, one important question raised by the new policy concerns the implications of the newly reported pension exposure on firms' stock returns in the period surrounding the announcement of the regulatory change. If firms' stock prices react to apparently minor changes in actuarial assumptions underlying firms' pension obligations, more effective corporate risk management policies would be needed to mitigate these exposures.

The objective of this research is to determine if the release of the exposure draft that preceded FRS 17 affected the abnormal returns of the securities of UK firms that voluntarily chose to adopt the new pension accounting rule in a significantly different way than the abnormal returns of firms that did not adopt the new rule ${ }^{1}$. We test this prediction using both an event study and variable effect methodology around the time of the announcement and over the four-y ear period before and after the announcement date. We condition any stock price reaction on the level of the firm's pension exposure and managerial discretion over the choice of valuation assumption. The reaction to regulatory induced changes in pension discounting assumptions should be of interest to corporate decision-makers, financial economists and accounting researchers for two reasons. First, strong evidence that capital market participants fail to account for the effect of unexpected changes in pension discount rate assumptions on UK firms' reported balance sheets would either challenge the efficient markets hypothesis or conflict with the conventional 'corporate finance' view (and FRS17) that the firm owns the pension surplus (e.g. Bulow, 1982). ${ }^{2}$ Second, these regulations are potentially value-relevant if around the time of regulation the stock price returns differ systematically across firms that use significantly different pension discounting rates. 
Our empirical results over the extended four-year window surrounding the announcement date seek to additionally control for other factors which might be expected to mitigate the interest rate sensitivity of stock prices to discount rate assumptions. These tests support the hypothesis that the extent to which the capital markets anticipate the effect of using different discount rates depends on the relative magnitude of the discounting rate assumptions underly ing firms' pension exp osures.

Our event-study empirical results show that allowing for control variables, the abnormal returns of firms that use market-based (FRS17) discount rate assumptions are sensitive to unexpected interest rate chan ges. These results support the hypothesis that the UK stock market is able to evaluate the effect of unexpected interest rate changes on the stock price returns of firms that adopt market-based discount rate assumptions. We conclude that the capital market rewards UK firms that manage interest rate risk by voluntarily using market-based discount rate assumptions. 


\section{INS TITUTIONAL B ACKGROUND AND PRIOR RESEARCH}

This section reviews the institutional background, the potential relevance of pension discounting to capital market participants and summarises the differences between UK and US pension accounting rules.

\subsection{Institutional Background}

Accounting standard setters have long debated the most appropriate basis for pension discounting assumptions with the result that many new pension accounting rules have been released over the last two decades. Table I summarizes the chronological development of pension accounting standards that are of interest to this study. Table I shows that US GAAP (Statement of Financial Accounting Standards 87 (SFAS87)) came into effect in 1985. SFAS87 requires firms to disclose various measures of pension liabilities in a footnote to the annual financial statements. The minimum net unfunded pension liability must also be recognized on the balance sheet using standard AA-bond discount rate assumptions.

\section{INSERT TABLE I ABOUT HERE}

The UK regulatory requirements are substantially different from SFAS87. Prior to 1 January 2005, Statement of Standard Accounting Practice 24 (SSAP24) gave UK actuaries considerable discretion over valuation frequency (every three years) and the methodology used to value the pension costs. SSAP24 merely required firms to state the main actuarial assumptions underly ing their estimated pension liabilities. Firms could use the flexibility in the standard to show either an asset or liability on the balance sheet. Moreover, actuaries could spread the pension costs over many years by smoothing the pension assets and discounting pension liabilities using a long-term equity-related expected rate of return. In the 1990s, many UK firms took advantage of this discretion and the rising stock markets by taking 'contribution holidays'. The recorded pension costs became meaningless and the subsequent stock market downturn forced many pension funds into deficit. 
Subsequently, the Accounting Standards Board (ASB) began to review the adequacy of the existing pension accounting rules. In June 1995, a discussion pap er was issued endorsing the existing position. In July 1998, the ASB released another discussion paper that showed a change of view on this issue. The ASB finally set out its current market value proposals in Financial Reporting Exposure Draft 20 (FRED20) in July 1999. Despite extensive industry opposition to its proposals, the ASB issued FRS 17 on 24 November 2000.

The ASB initially hoped that the new pension accounting rule would take effect from 2003. However, the proposals were strongly criticised on the grounds that they may force many UK firms to terminate their defined benefit plans (e.g. Financial Times, 30 December 2001). The ASB deferred the mandatory implementation of FRS 17 in July 2002 because of the controversy and the impending announcement by the International Accounting Standards Board (IASB). An important unresolved issue is determining the appropriate basis for discounting pension assets and liabilities, since there is a trade-off between the reliability and value relevance of the reported figures. ${ }^{3}$

Table II summarizes the different pension discounting assumptions that have caused such consternation for the regulatory bodies.

\section{INSERT TABLE II ABOUT HERE}

\subsection{Review of Prior Research}

The prior US-based empirical research has shed considerable light on the issue of whether pension liabilities are fully reflected in stock prices. Chen and D'Arcy (1986) examine whether the market is sensitive to different pension interest rate assumptions around the issue date of US pension accounting proposals. This paper analyses the market performance of the securities of firms with varying pension plan interest rate assumptions around the release date of Financial Accounting Standards Board No. 36 (FASB36). They investigate the interest sensitivity of the stock returns of firms that differed both in the level of pension exposure and in the magnitude of discount rate assumptions. They find that the securities of firms that make a low interest rate assumption outperformed the securities of other samples and provided significantly positive risk adjusted returns. However, Chen and D'Arcy (1986) can be criticized for 
failing to control for industry effects or for the management discretion that can be used to ameliorate the magnitude and/or timing of their reported pension exposures.

This raises the possibility that the choice of interest rate assumption may be value relevant to firms (Fogarty and Grant, 1995). Blankley and Swanson (1995) investigate the behavior of the discount rate, expected rate of return on plan assets and exp ected rate of future compensation using a sample of 303 US firms from 1987-1993. They find that firms have changed their discount rates less frequently than one would expect if they had fully complied with the SFAS 87 requirements. Other empirical studies examine the motivations of the managers of over-funded defined benefit pension funds for changing interest rate assumptions (e.g. Thomas, 1989; Ghicas, 1990). Godwin et al. (1997) provide evidence that the managers of US-firms change actuarial-interest-rate assumptions to manage earnings.

This suggest that the considerable managerial scope in SSAP 24 might allow UK managers to voluntarily adopt market-based valuation assumptions to engage in earnings management. Klumpes and Whittington (2003) examine the factors that explain variations in UK firms' decision to switch to the market-based valuation method required by FRS 17. They find a significant relation between the switching decision and pension plan funding. These findings suggest that firms' switching decisions are potentially explained by the characteristics of the pension plans rather than by the US earnings management motivation.

Nevertheless, most of the financial press criticisms of FRS 17 are based on concern that the value of the sponsoring firm will be adversely affected by the use of marketbased pension discounting methods. These fears are not supported by the extensive US literature (e.g. Oldfield, 1977; Gersovitz, 1980; Feldstein and Seligman, 1981; Feldstein and Morck, 1983; Daley, 1984; Landsman, 1986; Barth, 1991; Barth et al., 1992 and Sami and Shahid, 1997). All of these studies evaluate the information content of likely determinants of a firm's market value using cross-sectional models that assume that pension liabilities are determined using a "spin-off" or termination value basis. These studies typically conclude that unfunded pension obligations influence stock prices if unfunded pension liabilities can be shown to affect market value. However, Chen and D'Arcy $(1986,213)$ restrict the implications of this 
literature on the grounds that funding policy depends significantly on the accuracy of estimates of pension liabilities. 


\section{D EVELOPMENT OF HYPOTHES ES}

The results of the studies discussed above suggest that the most important determinants of pension costs and liabilities are the underlying assumptions. The issue of whether the stock market takes account of the difference between market based (FRS17) and actuarial (SSAP24) valuation assumptions is interesting because the underlying assumptions of SSAP 24 differ significantly from those of FRS17. The research hypothesis examines the market sensitivity to pension valuation assumptions by UK firms. The hypothesis is conditioned by whether a firm voluntarily chooses to switch to market-based discount rate assumptions around the time of the rule-change. ${ }^{4}$

Firms adopting market-based valuation techniques are likely to be more conservative in their forecast to try to minimize the aforementioned stock price volatility. Such companies are more likely to use rates that reflect contemp orary market conditions to hedge their pension liability. Since prime corporate bond rates and equity market conditions were unfavourable in the late 1990s, firms choosing to voluntarily adopt FRS 17 will tend to report higher pension liabilities and net pension expense. The proposed rules will increase the volatility of reported pension values and will be impounded into prices if the market is efficient. Thus, if pension liabilities are discounted at market rates, early adopters should have no excess returns since they have already revealed the effects of the proposed new standard in their pension exposure. Building on this conjecture, the first hyp othesis predicts that investors either will have already rewarded, or will reward on discovery, firms using market-based actuarial valuation assumptions by incorporating these changes into the market valuation of the firms' funded pension liabilities during the pre-announcement period.

Hypothesis 1: Ceteris paribus, the stock prices of UK firms sponsoring pension plans with market-based pension valuation assumptions will react more favorably to the proposed new pension accounting rules in the immediate pre-announcement period than the stock prices of industry match paired firms that have low pension expense or that use non-market valuation assumptions.

Unexpected changes in interest rates should affect various components of firms' exposure. If interest rates change rapidly and market conditions are volatile, the sensitivity of reported pension assets and/or liabilities will be potentially value- 
relevant to capital market participants. Ceteris paribus, firms that voluntarily adopt market-based valuation methods (as required by FRS 17) allow capital market participants to quickly incorporate unanticipated changes in interest rates into their reported pension exposure. Accordingly, the stock price returns of switch firms are expected to incorporate firm risk associated with the option to terminate pensions. We predict that the stock prices of UK firms that voluntarily switch to market-based pension discount rate assumptions will be more sensitive to unexpected interest rate changes than those that retain actuarial assumptions. Our empirical tests examine this prediction controlling for the association between stock returns and the effect of unexpected changes in interest rates on earnings.

UK firms are required, during an extended transitional period, to report their pension liabilities discounted using both the FRS 17-based AAA corporate bond rate and the SSAP 24-based long-term expected rate of return on pension assets. This difference is likely to be directly associated with the impact of unanticipated changes in interest rates on returns. Since firms can exercise discretion to update these latter assumptions more frequently to enhance the interest-sensitivity of their reported pension assets and liabilities, their stock price returns should also be more sensitive to these differences.

The second hypothesis of this study posits that stock price returns of firms that voluntarily adopted market-based discount rate assumptions will be negatively associated with the effect of these changes on the interest-rate sensitive pension assets and liabilities:

Hypothesis 2 Ceteris paribus, the association between the stock returns and the effect of unexpected interest rate changes on pension assets and liabilities will be significantly stronger for UK firms that voluntarily used market-based discount rate assumptions than UK firms that used actuarial based assumptions. 


\section{METHODOLOGY AND S AMPLE S ELECTION}

\subsubsection{Methodology-Hypothesis 1}

In order to test hypothesis 1 , the standard market model is used to calculate the abnormal return (AR), for security $j$ on event day $t$ as follows:

$$
A R_{j t}=R_{j t}-\left(\hat{\alpha}_{j}+\hat{\beta}_{j} R_{m t}\right)
$$

where

$R_{j t}=$ the rate of return on security $j$ on event day $t$, and

$R_{m t}=$ the rate of return on the FTSE 100 value-weighted index on event day $t$.

We use the mark et model to calculate ordinary least squares estimates of the intercept, $\alpha_{j}$ and gradient, $\beta_{j}$ over the 100 day estimation period $t=-145$ to $\mathrm{t}=-46$ that is taken relative to the event day $\mathrm{t}=0$. We then compute daily abnormal returns for each firm over the period $t=-45$ to $\mathrm{t}=+10$. The cumulative abnormal return (CAR) over the event period $\mathrm{K}$ to $\mathrm{J}$ is defined as:

$$
C A R_{j}=\sum_{K}^{L} A R_{j t}
$$

The mean cumulative abnormal return for a sample of $\mathrm{N}$ stocks is:

$C A R=\frac{1}{N} \sum_{j-1}^{N} C A R_{j}$

The mean cumulative abnormal return is completed for several intervals around event day $t=0$ and is expected to be zero in the absence of abnormal performance. The Dodd and Warner (1983) mean standardised cumulative abnormal return can be used to test the significance of any prediction error. This test statistic is calculated by standardising the daily prediction by its standard deviation $\left(\mathrm{s}_{\mathrm{jt}}\right):^{5}$

$$
S A R_{j t}=A R_{j t} / S_{j t}
$$

and then cumulating the standardised abnormal return over the period $\mathrm{K}$ to $\mathrm{J}$ :

$$
S C A R_{j t}=\sum_{t-K}^{L} \frac{S A R_{j t}}{\sqrt{L-K+1}}
$$

For a sample of $N$ securities, the approp riate test statistic is:

$$
\mathrm{z}=\sum_{\mathrm{j}=1}^{\mathrm{N}} \frac{\mathrm{SCAR}_{\mathrm{j}}}{\sqrt{\mathrm{N}}}
$$

$S A R_{j t}$ and $z$ will be normally distributed with a unit root if there is no abnormal performance. 
The next section introduces a 'variable effect' methodology to study the association between both short-term and long-term stock returns and the interest rate sensitivity of firms' pension liabilities. We then introduce the experimental design and provide descrip tive statistics for the put option termination option and other control variables.

\subsubsection{Empirical Modelling Specification - Hypothesis 2}

The event study methodology outlined above is unable to discriminate whether the observed market response to a proposed new pension accounting rule is associated with other sources of firm income and expenses that are entirely within management control, as opposed to those arising from external events. For instance, unexpected changes in interest rates are likely to directly impact a company's pension-related earnings, its fixed rate bonds and have second order-effects on equity investments and even the prices of a company's goods. Standard event study methods cannot control for these sensitivities.

This section outlines an alternative 'variable effect' methodology introduced by Bulow et al. (1987), to study the posited association between both short-term and long-term stock returns and the interest rate sensitivity of firms' assets and liabilities during the four years immediately preceding the issue of new pension accounting rules. Consistent with Bulow et al. $(1987,97)$ we postulate that the return on firm i, in month $\mathrm{t}\left(\mathrm{r}_{\mathrm{it}}\right)$, as specified by equation (1), can be re-expressed as:

$$
\mathrm{r}_{\mathrm{it}}=\alpha_{\mathrm{i}}+\mathrm{B}_{\mathrm{it}} \Delta \mathrm{R}_{\mathrm{t}}+\mathrm{u}_{\mathrm{it}},
$$

where $\alpha_{i}$ is the normal required expected return on firm $i$ and $B_{\text {it }}$ reflects its sensitivity to interest rate news, here proxied by the change in the long-term actuarial-based interest rate $R_{t}$, and $u_{i t}$ is a random error term. $\Delta R_{t}$ depends on the firm's characteristics at time $t$ that are subject to unexpected changes in the interest rate sensitivity of funded pension liabilities (FPL), funded pension assets (FPA), and longterm debt (LTD). ${ }^{4}$ In addition such events will impact $\mathrm{PA}^{\mathrm{A}-\mathrm{M}}$ and $\mathrm{PL}^{\mathrm{A}-\mathrm{M}}$, the amount of the difference between long-term actuarial assessed and short-term market-based valuation assumptions on the pension assets and liabilities, respectively. ${ }^{5}$ These terms can be deflated by $V_{i t}$, the equity value of firm $i$ in period $t^{6}$. It is also assumed that the evolution of the stock return is influenced by $\mathrm{R}^{\mathrm{M}}{ }_{\text {it }}$, the return on the market portfolio. 
Including these terms yields the following cross-section time series equation, which provides the basis for our empirical work:

$$
\begin{aligned}
r_{i t}=\alpha_{i} & +\gamma_{0} \Delta R_{t}+\gamma_{1} \Delta R_{t} F P L / V_{i t}+\gamma_{2} \Delta R_{t} L T D / V_{i t}+\gamma_{3} \Delta R_{t} P L^{A-M} / V_{i t} \\
& +\gamma_{4} \Delta R_{t} F P A / V_{i t}+\gamma_{5} \Delta R_{t} P A^{A-M} / V_{i t}+\gamma_{6} P U T / V_{i t}+\gamma_{7} C A L L / V_{i t}+\varepsilon_{i t}
\end{aligned}
$$

Equation (8) can be estimated, given cross-section time series data using ordinary least squares, to yield unbiased estimates of the parameters. This model specification differs from that suggested by Bulow et al. (1987) by including, in addition to the variables posited to be influenced by unexpected interest rate changes, firms' strategic option to terminate pensions (PUT/ $\left.\mathrm{V}_{\mathrm{it}}\right)$, emp loyees call options over improved benefit above the regulatory minimum $\left(\mathrm{CALL} / \mathrm{V}^{\mathrm{it}}\right)$, as well as periodic earnings before interest and pension expense $\left(\mathrm{NI} / \mathrm{V}_{\mathrm{it}}\right)$ that Easton (1999) suggests should be incorporated into stock price returns models. Controlling for these explanatory variables of security returns also allows for improved interpretation of the magnitude and significance of the coefficients (Scholes, 1987). ${ }^{7}$

\subsection{Sample Selection Procedures}

We test our hypotheses by comparing the returns of firms that voluntarily switched to new market-based valuation methods in their financial reports with those of industrymatched, non-switch firms that reported their pension funding ratios using traditional actuarial valuation methods. We use industry matching to control for industry-related variables that affect pension liabilities because pension funds in the same industry use similar mortality and turnover assumptions (Ghicas, 1990). Industry-matched pair firms were created on the basis that a different valuation policy or a significantly different level of pension expense existed between the two groups. In the first case, firms switching to market-based actuarial valuation methods can be distinguished from an industry-matched pair of either (1) firms which switched but had relatively low pension expense; or (2) firms that continued to rely on traditional actuarial valuation methods. Industry matching was also conducted on the basis that pension exposure is a significant factor (above 5\%) in a firm's total mark et value at balance sheet date. These criteria are important because the hypothesis assumes that switch firms can be easily distinguished from non-switch firms. Switch firms reported the new method, the old method and a decrease in pension expense arising from the 
switch. Subsequently, these switches were confirmed in the equivalent pension fund annual report. The number of switches in 1996, 1997 and 1998 were similar (12, 10 and 9 , respectively).

Accordingly, rigorous sample selection procedures were followed that limited the total industry matched-pair sample to the 31 switching firms and 31 non-switching firms that are listed in Table III. Firms are matched in the following categories: building and construction, brewing, engineering, financial services, food manufacturing, industrial instruments, leisure, manufacturing, medical packaging and distribution, publishing, resources, retail, services, travel, technology, telecommunications and utilities. These firms (i) have complete, relevant financial and actuarial data available on Datastream over the entire study period 1994-99; (ii) sponsor pension funds for which complete and relevant data are available over the corresponding period (collected by the authors) and (iii) are in continuous existence during the five years prior to the issue of the standard (i.e. when UK managers first had an opportunity to elect to use market-based valuation methods).

\section{INSERT TABLE III ABOUT HERE}

\subsubsection{Data - standard event study}

Our first hypothesis was tested using daily Datastream returns for the 3 sub-p eriods summarized in Table IV. Parameter estimates are based only on 100 trading days in the pre-event period. The 45 days immediately preceding the event are excluded to avoid the introduction of noise in the model when it is believed that the market anticip ates the event. Only 10 days were used for the post-event analysis. It would be extremely difficult to attribute price changes over a long post event period to a specific source of information.

INSERT TABLE IV ABOUT HERE 


\subsubsection{Descriptive Statistics - Control Variables for variable effects event study}

Data on pension assets and liabilities are drawn from DATASTREAM. The following variables are used in the study for examin ing both switching and non-switching firms:

$p_{i t}=$ return on firm $\mathrm{i}$, in month $\mathrm{t}$

$P L_{t}=$ actuarially-assessed pension liabilities at the end of year $\mathrm{t}$, as reported by the sponsoring firm's annual report. It should be noted that this figure is reported according to the ratio of actuarial assets (assumed to equal $P A_{t}$ ) to actuarially-assessed pension liabilities as required by SSAP 24.

$P A_{t}=$ actuarially-assessed pension assets at end of year $\mathrm{t}$, as reported by the sponsoring firm's annual report at a smoothed (i.e. five year average) market value in the pension footnote in accordance with SSAP 24.

$L T D_{t}=$ long term corporate debt at end of year $\mathrm{t}$, obtained from DATASTREAM.

$N I_{t}=$ net earnings for relevant year, before pension and interest expense, divided by market value of equity in year $\mathrm{t}$, obtained from DATASTREAM.

$P L^{A-M}=$ difference between actuarial and market-based value of pension fund liabilities during year t. The difference is obtained from firms' pension footnote disclosures of both (a) the discounted pension liabilities when using the actuarial method (SSAP 24), and (b) the most recent 1 y ear UK corporate bond rate (FRS 17). $P A^{A-M}{ }_{t}=$ difference between actuarial and market-based pension asset disclosures in the footnote. The difference is obtained from firms' pension footnote disclosures of both (a) the actuarially-assessed (SSAP 24) pension assets; and (b) the current market (i.e. unsmoothed per FRS 17) value of pension fund assets during year $t$.

$\Delta R_{i t}=$ unexpected change in interest rates during year $\mathrm{t}$ for firm $\mathrm{i}$, defined as the difference between the market-based interest rate as at the date of the release of the firm's annual report and the most recent 1 year UK corporate bond rate.

Table V provides descriptive statistics for the control variables for both switch and non-switch sample firms. The differences in pension asset and liability rate valuation assumptions as between switching and non-switching firms are statistically different. This implies that switching firms are likely to be relatively more sensitive to the effects of unexpected discount rate changes. These results tentatively confirm our hypothesis that UK firms' switching decisions impact observed variations in discount valuation rate assumptions. However, more sophisticated multivariate tests are needed 
to establish whether such variations also bear up on the value relevance of these observed differences for each of our sub-samples of switch and non-switch firms.

\section{INSERT TABLE V ABOUT HERE}

\section{EMPIRIC AL TES TS}

\subsection{Results}

Table VI reports the daily abnormal returns (ARs) and cumulative abnormal returns (CARs) for the market valuation group, the low pension expense group and the nonmarket valuation group for day $t=-45$ through day $\mathrm{t}=+10$. On November 301999 (day $t=0$ ), the market valuation group experienced a statistically significant positive mean abnormal return. This suggests that the market responds positively to the unexpected news for firms that voluntarily switch to market-value based discount rates. This result occurred on the day that the proposed change to UK pension accounting rules (FRED20) was promulgated. Since, by construction, the non-market valuation group represented firms with high pension exposure, any information that adversely affected pension plans would be expected to influence the market price of these firms inordinately. By contrast, the non-market valuation group experienced an insignificant positive mean abnormal return and the low pension expense group exhibited insignificant negative abnormal returns. The market valuation group did not rep ort any significant mean abnormal returns during the 8 trading days before or after the event date.

\section{INSERT TABLE VI ABOUT HERE}

The actual market reaction to the new pension accounting proposals might be more pronounced than revealed above because the market might anticipate the release of the proposed regulations. Figure 1 plots the mean cumulative abnormal returns for each group. Figure 1 shows that the CARs of the market-based and the non-market based groups moved very closely before the announcement date, with the latter fluctuating around zero between $\mathrm{t}=-18$ and $\mathrm{t}=2$. By contrast, the CAR of the lowexposure group was consistently the lowest of the three, and falls as low as - 0.08. 
Consistent with stock market efficiency, we conclude that FRED 20 seems to have been anticipated by the market a few days before it was released.

\section{INSERT FIGURE 1 ABOUT HERE}

\subsection{Sensitivity Tests - Hypothesis 1}

Chen and D'Arcy $(1986,218)$ examine the sensitivity of their results to the immed iate pre- and post-announcement period because the length of the event window is arbitrary. Following Chen and D'Arcy, we test whether the mean abnormal returns in the immediate pre- $(t=-5$ to $t=-1)$ and post-announcement $(t=1$ to $t=5)$ periods are significantly different from zero. Table VII reports Z-statistics for the mean abnormal returns over the five days prior to and after the release of the new proposals. ${ }^{6}$ In the immediate pre-announcement period, the mean abnormal return of the market valuation group is positive and statistically different from zero at the 5 percent level. The mean abnormal returns are negative at the 1 percent level in the immed iate post-announcement period. By contrast, the mean abnormal returns for both control groups in the immediate pre-announcement and post-announcement periods are not significantly different from zero.

\section{INSERT TABLE VII ABOUT HERE}

The short-event window methodology used in this study calculates an abnormal return after the market factor is removed (equation 1). Thus, the mean abnormal returns represent excess returns after adjusting for the positive relative volatility of the securities and the total market movement. The significant abnormal return for the market valuation group for the period $t=-5$ through -1 (Table VII) after the market movement has been removed can be attributed to the pending release of FRED 20 as predicted by Hyp othesis 1 .

The Z-scores reported in Table VII might be over-estimated because the standard deviation estimated under equation (5) assumes total independence. As a further sensitivity test, we correct for cross-sectional correlation by repeating the tests reported in Table VII using a slightly adjusted event date to reflect the uncertainty 
over the accounting rules over time. The power of these tests is relatively invariant to the exact choice of event date.

\subsection{Multivariate Regression Tests - Hypothesis 1}

The time series empirical tests ignore the possibility of errors in the estimation of the parameters. We therefore use a fixed effects model to investigate whether the models of abnormal returns for firms using market and non-market-based discount rate assumptions have significantly different explanatory power for the postannouncement period. ${ }^{7}$

Table VIII presents the results of a regression of announcement returns on abnormal returns. We allow the coefficient on abnormal returns to vary across the first and last half of the sample period. This is accomplished by interacting the abnormal returns with a time-period dummy variable POST $_{\mathrm{ANN}}$, which takes the value of 1 if the observation is post announcement date or later and 0 otherwise. If there has been no change in the effect of discount rate on market performance across time, the coefficient on the interaction term should be zero. Alternatively, a significant coefficient confirms that there has been a change in the intensity with which the market has approached the interpretation of market-value discount rate assumptions. The regression is estimated separately for the market valuation abnormal returns $\mathrm{AR}_{\mathrm{Mkt}}$ and non-market valuation abnormal returns $\mathrm{AR}_{\mathrm{NMk}}$, and with both metrics together and finally after controlling for the sub-sample firms with low pension expense $\left(A R_{L P E}\right)$. The purpose of the last sp ecification is to allow a test of differences in the coefficients of the two predicted error metrics.

In the separate $\mathrm{AR}_{\mathrm{Mkt}}$ and $\mathrm{AR}_{\mathrm{NMkt}}$ regressions, the coefficient on $\mathrm{AR}_{\mathrm{NMkt}} * \mathrm{POST}_{\mathrm{ANN}}$ (0.002) is significantly different from that of $\mathrm{AR}_{\mathrm{Mkt}} * \mathrm{POST}_{\mathrm{ANN}}$ (0.772). An F-test cannot reject the null of equality for the two coefficient estimates, $p$-value $=0.001$. This result suggests that in the pre-announcement portion of the sample period, investors do not reveal a strong preference for one measure over the other. Turning to the post-announcement portion of the sample period, we find that the coefficient estimates on the time-period interaction terms are significant for both $A R_{M k t}$ and $\mathrm{AR}_{\mathrm{NMk}}$, suggesting that announcement returns have become more strongly associated with abnormal returns in the post-announcement sample period. An F-test reveals that 
the difference in the mean abnormal return coefficients is significant (e.g., $\left[\mathrm{AR}_{\mathrm{Mkt}} *\right.$ $\operatorname{POST}_{\mathrm{ANN}} \ngtr\left[\mathrm{AR}_{\mathrm{NMk}} * \mathrm{POST}_{\mathrm{ANN}}\right], \mathrm{p}$-value 0.0001). Thus, it appears that the market has shifted toward responding to the market-based figure rather than to the nonmarket based discounting rate assumption. Overall, we find that investors are displaying a greater sensitivity in the immediate post-announcement period to discounting rate assumptions for $\mathrm{AR}_{\mathrm{Mkt}}$ over $\mathrm{AR}_{\mathrm{NMlt}}$. These results confirm our predictions.

\section{INSERT TABLE VIII ABOUT HERE}

\subsection{Multivariate tests - Hypothesis 2}

The results of estimating equation (8) for the pre-announcement four-year event window are reported in Panel A of Table IX. For switch firms, this equation provides evidence that the pension put $(P U T)$ is sensitive to unexpected changes in durationmatched pension liability rates. This result is consistent for non-switch firms. The model for non-switch firms also has a higher goodness of fit than for the switching model (Adj $\mathrm{R}^{2}=0.206$ versus 0.118 ). Interestingly, only the $N I / V^{i t}$ variable is statistically significant. This result corroborates the findings of prior research that the stock market is unable to discriminate between the impact of unexpected interest rates on pension and core earnings sources for non-switch firms.

\section{INSERT TABLE IX ABOUT HERE}

Panel B reports the results for the post-announcement four-year window. The Adjusted $\mathrm{R}^{2}$ and model significance for the overall models is higher for switch firms than for non-switch firms. The lack of significant coefficients for the UK samples is generally consistent with our null hypothesis. By contrast, most of the coefficients relating to the insurance-related variables and the implicit option estimates PUT and $C A L L$ are in the predicted direction but are not significant. In addition, coefficients of variables representing pension assets $(\mathrm{PA} / \mathrm{V})$ are significant for switching firms and 
long-term debt (LTD) and pension liabilities (PL/V) are statistically significant for non-switch firms. These results support the notion that the stock market valuation of firms' implicit termination options is strongly conditioned by firms' switching choices.

\subsection{Sensitivity Tests}

Further sensitivity analysis was conducted to increase our confidence about the robustness of our results. First, we included a number of control variables used in prior value-relevance research in the regressions (e.g. lagged earn in gs). We eliminated observations with negative earnings. Potential endogeneity of earnings, market returns and industry match-paired firms was recognised by running two-stage least squared regressions for equation (3). We also eliminated observations of firms in regulated industries, where different accounting standards and disclosure requirements may apply (e.g. banking, life insurance, telecommunications, and utilities). We also rep eated the analy sis sep arately for only firms with a minimum net pension liability or asset (i.e. which are less than 1\% of mark et value of equity) and for outlier firms with relatively high and low debt. Finally, we repeated the analyses sep arately for the years 1999-2000 and 2001-02, when presumably the effects of the long bull stock market may have caused substantially more UK firms to have over funded pension plans. In all cases the regression results are not affected and so are not separately reported.

We also conducted various diagnostic and sensitivity tests in order to examine the robustness and efficiency of our multivariate results. First, we incorporated a number of other control variables, such as lagged earnings and earnings multiplied by the interest rate factor: none of these significantly affected our overall results. Second, homoscedasticity of the residuals was tested using the White (1980) test for heteroscedasticity to examine correlation of the error terms. The White test rejects the null hypothesis of homoscedasticity for the sample, but the findings are robust to using White heteroscedasticity-consistent standard errors. Based on White standard errors, the null hypothesis is rejected at the 0.01 level for the pooled sample. Therefore, we conclude that our fixed-effects results are not unduly biased by the normality problem. 
New UK pension accounting rules imposing market-consistent valuation of pension assets and liabilities effectively removed considerable discretion over firms' pension discount rate assumptions. The proposals were developed over a period where many firms' sponsored pension funds experienced both declining interest rates and relatively poor stock market performance. We predict the proposals differentially affected the stock price returns of industry match-paired samples of UK firms that either did or did not voluntarily adopt the market-based discount rate assumptions.

The short time frame for the event study identifies positive cumulative abnormal returns for firms switching to market-based pension discount rates twenty days prior to the announcement date of the proposed new pension accounting rules. By contrast, the performance of the industry match pair samples of non-switching firms around the time of the announcement is consistently insignificant.

The post-announcement differential market response to sample firms that either did or did not use discounting rate assumptions is robust to the results of a multivariate fixed-effects regression. These findings provide tentative support to earlier findings concerning the market sensitivity to the issue of US pension accounting proposals on firms that choose differential pension interest rate assumptions (Chen and D'Arcy, 1986). Our results extend the prior literature by additionally controlling for both industry effects in the sample selection procedure and UK firm managers' discretion over market-based discount rate assumptions.

We also exploit a variable effects event study methodology to examine the association between stock returns and the effect of unexpected interest rate changes on interest sensitive pension assets and liabilities, over four year transitional periods both prior to and following the announcement. This tests a further hypothesis that stock prices of UK firms' are sensitive to interest rate sensitivity of pension discount rate assumptions and their strategic option to voluntarily terminate these schemes to new employees. Our findings are gen erally consistent with this hypothesis for the post-announcement period, even after controlling for other pension and firm related sources of value that are sensitive to the effect of unexpected interest rate changes on firm stock returns. 
This conclusion is reasonably robust because alternative methodological approaches and data from several different years were used. The put option estimate is significantly associated with stock price returns even after controlling for business and economic factors affecting the interest rate sensitivity of firms' security prices. For those firms exercising this discretion by using standard discounting assumptions, the put option estimate that is premised on pension liabilities estimated consistently with solvency regulations significantly associated with stock price returns; for other firms the put option estimate premised on pension liabilities estimated consistent with financial reporting rules. This suggests that this amount is potentially value-relevant to capital market participants.

These empirical results also support our prediction that the difference between (actuarial cost based versus market-based) pension asset values and (equity-linked versus corporate bond-linked liability) discount rates is potentially value-relevant to capital market participants for assessing the option to terminate pension plans. Thus, we provide some evidence that market valuation assumptions of firms reflect longduration contractual liabilities and assets in respect of their workforce. 


\section{Footnotes}

1. It could be alternatively argued that disclosure, rather than recognition of pension liabilities, is sufficient information. However Landsman and Ohlson (1990) provide evidence that the stock market appears to under-react to the disclosure, rather than recognition, of information inherent in net pension assets, and conclude that this is caused by market inefficiency.

2. The question of whether actuarial or market-based interest rates should be used to discount pension liabilities is also closely related to the broader conceptual issue of how pension liabilities should be defined and measured (Klumpes, 2001).

3. Prior UK GAAP did not mandate a uniform actuarial methodology for calculating pension assets or liabilities, although FRS 17 proposes to use a more standard market-based approach (para 12). Consequently it is not possible to empirically examine this issue directly in our study, although we partially attempt to overcome this problem by dichotomizing our sample of firms between those likely to use short-term and long-term pension contracts.

4. Consistent with Landsman (1986) and Barth (1991), we attempt to overcome this potential problem by examining the market impact of the full pension liability.

5. The value of $\mathrm{s}_{\mathrm{jt}}$ is given by (Chen and D'Arcy, 1986):

$$
s_{j t}=\left[s_{j}^{2}\left(1+\frac{1}{D_{j}}+\frac{\left(R_{m t}-\bar{R}_{m}\right)^{2}}{\sum_{\tau=1}^{D_{j}}\left(R_{m \tau}-\bar{R}_{m}\right)^{2}}\right)\right]^{1 / 2}
$$

Where $s_{j}^{2}=$ residual variance for security $j$ from the market model regression,

$D_{j}=$ number of observations during the estimation period,

$R_{m t}=$ rate of return on the market index for day $t$ of the event period,

$R_{m}=$ mean rate of return on the market index during the estimation period,

$R_{m t}=$ rate of return on the market index for day $t$ of the estimation period.

6. The authors also calculated mean abnormal returns over various other time period intervals. Consistent with the findings reported in this section, the mean abnormal returns of market valuation group are positive in the pre-announcement period but 
negative in the post announcement period. However, the man prediction errors of the low pension and non market groups are not statistically different from zero in either the pre- or post-announcement period. None of the empirical results are affected when companies cross-listed on the New York Stock Exchange.

7. We are grateful to an anony mous referee for this point. The tests reported in table VIII below were robust to alternative specifications of the pre- and postannouncement periods, after controlling for other financial variables for each firm and conditioning by market capitalisation. 


\section{References}

Accounting Standards Committee 1988. SSAP 24: Accounting for the cost of pensions. ASB: London.

Accounting StandardsBoard 2000. FRS 17: Retirement Benefits, ASB: London.

Barth, M.E. 1991. Relative measurement errors among alternative pension asset and liability measures. Accounting Review 66: 433-63. Barth, M., Beaver, W.H. and Landsman, W.R. 1992. The market valuation implications of net periodic pension cost components. Journal of Accounting and Economics (15): 27-62.

Blankley, A.I. and Swanson, E.P. 1995. A longitudinal study of SFAS 87 pension rate assumptions. Accounting Horizons. (December) 9(4): 1-21.

Bulow, J. 1982. What are corporate pension liabilities? Quarterly Journal of Economics, 97: 435-52.

Chen, K.C. and S.P. D'Arcy. 1986. Market sensitivity to interest rate assumptions in corporate pension plans. Journal of Risk and Insurance. (June) 53(2): 209-225.

Clark, P. 1998. IAS 19 is a big step towards IOSCO endorsement. Accountancy Magazine, March. Page numbers?

Daley, L. 1984. The valuation of reported pension measures for firms sponsoring defined benefit plans. The Accounting Review (April): 111-198.

Dodd, P. and Warner, J.B. 1983. On corporate governance: a study of proxy contests, Journal of Financial Economics 11(4): 401-438.

Feldstein, M.S. and Morck, R. 1983. Pension funding decisions, interest rate assumptions, and share prices. In Financial Aspects of the United States Pension System, ed., Z. Bodie and J.B. Shoven. Chicago: University of Chicago Press.

Feldstein, M.S. and S. Seligman 1981. Pension funding, share prices and national savings. Journal of Finance (September), pp. 801-824.

Financial Accounting Standards Board 1985. Statement of Financial Accounting Standards No. 87. Employer Sponsors' Pension Accounting.

Fogarty, T.J. and J. Grant. 1995. Impact of the actuarial profession on financial rep orting. Accounting Horizons. (September) 9(3): 23-33.

Gersowitz, M. 1980. Economic consequences of unfunded vested pension benefits. Working Paper. National Bureau of Economic Research.

Ghicas, D.C. 1990. Determinants of actuarial cost method changes for pension accounting and funding. The Accounting Review (April)., pp. 384-405.

Godwin, J.H., S.R. Goldberg and J.E. Duchac. 1997. An empirical analy sis of factors associated with changes in pension-plan interest-rate assumptions. Journal of Accounting, Auditing and Finance, 305-322.

Gopalakrishnan, V. and T.F. Sugrue. 1993. An empirical investigation of stock market valuation of corporate projected pension liabilities. Journal of Business Finance and Accounting. 711-723.

International Accounting Standards Committee. 1996. Exposure Draft E54: Employee Benefits. IASC: London. 
-----. 1997. IAS 19 (Revised): Accounting for Employers' Pension Costs. IASC: London.

Klumpes, P.J.M. 2001. Implications of four theoretical perspectives for pension accounting research, Journal of Accounting Literature, Vol. 20, 30-61.

Klumpes, P.J.M. and M. Whittington. 2003. Determinants of Actuarial Valuation Method Changes for Pension Funding and Reporting: Evidence from the UK, Journal of Business Finance and Accounting (25\&25):781-783.

Landsman, W. 1986. An empirical investigation of pension fund property rights. Accounting Review 61: 662-91.

And J.A. Ohlson. 1990. Evaluation of market efficiency for supplementary accounting disclosures: the case of pension liability, Contemporary Accounting Research 2 (October): 1-30.

Mittelstaedt, H.F and P.R. Regier 1993. The market response to pension plan terminations. The Accounting Review (January). pp. 1-27.

Oldfield, G.S. 1977. Financial aspects of the private pension system. Journal of Money, Credit and Banking, pp. 48-93.

Sami, H. and A. Shahid 1997. Financial accounting standards and the relev ance and reliability of accounting information: the case of accounting for pensions. Accounting Enquiries 6(2): 149-186.

Scholes, M. Comment on Marcus et al., in Bodie, Z, Shoven, B. and D. Wise eds., Issues in Pension Economics, University of Chicago Press, Chicago.

. And M. Williams. 1977. Estimating betas from nonsynchronous data, Journal of Financial Economics, 5(3): 309-327.

Sharpe, W. 1976. Corporate pension funding policy, Journal of Financial Economics, 4(2): 183-194.

Thomas, J.K. 1989. Why do firms terminate their overfunded pension plans? Journal ofAccounting and Economics. 11: 361-398. 
Table I

\section{Chronology of Development of UK, US and International Pension Accounting Standards}

\begin{tabular}{|c|c|c|}
\hline$\overline{\text { DATE }}$ & EVENT & DESCRIPTION \\
\hline $\begin{array}{l}\text { December } \\
1985\end{array}$ & FASB issues SFAS 87. & $\begin{array}{l}\text { SFAS } 87 \text { requires disclosure of } \\
\text { several measures of pension } \\
\text { liabilities in a footnote and } \\
\text { recognition of the net unfounded } \\
\text { pension liability in the Balance } \\
\text { Sheet. }\end{array}$ \\
\hline May 1988 & $\begin{array}{l}\text { ASB issues SSAP 24; effective } \\
1990\end{array}$ & $\begin{array}{l}\text { SSAP } 24 \text { requires footnote } \\
\text { disclosure of certain actuarial } \\
\text { assumptions underlying the } \\
\text { reported pension cost calculation. } \\
\text { Considerable discretion over } \\
\text { actuarial method and actuarial } \\
\text { assumptions permitted. }\end{array}$ \\
\hline June 1995 & ASB issues Discussion Paper & $\begin{array}{l}\text { ASB explores problems with } \\
\text { SSAP 24, including lack of } \\
\text { standard disclosures }\end{array}$ \\
\hline $\begin{array}{l}\text { October } \\
1996\end{array}$ & IASC issues Exposure Draft 54 & $\begin{array}{l}\text { IASC proposes valuation of } \\
\text { pension liability using market- } \\
\text { based assumptions }\end{array}$ \\
\hline 6 April 1997 & $\begin{array}{l}\text { Minimum } \\
\text { Requirements of Pensions Act } \\
1995 \text { effective for periods } \\
\text { beginning on or after this date }\end{array}$ & $\begin{array}{l}\text { Actuaries required to measure } \\
\text { value of pension plan liabilities } \\
\text { using prescribed assumptions and } \\
\text { adjust to reflect current market } \\
\text { conditions }\end{array}$ \\
\hline March 1998 & IASC issues Revised IAS 19 & IASC implements ED 54 \\
\hline July 1998 & $\begin{array}{l}\text { ASB issues further Discussion } \\
\text { Paper }\end{array}$ & $\begin{array}{l}\text { ASB restates intention to require } \\
\text { UK firms to recognise pension } \\
\text { liability on balance sheets; favours } \\
\text { market-values }\end{array}$ \\
\hline $\begin{array}{l}30 \\
\text { November } \\
1999\end{array}$ & $\begin{array}{lr}\text { ASB issues proposed changes to } \\
\text { pension accounting rules } \\
\text { (FRED20) } & \end{array}$ & $\begin{array}{l}\text { UK firms to recognise pension } \\
\text { liability using market-based } \\
\text { assumptions }\end{array}$ \\
\hline $\begin{array}{l}25 \\
\text { November } \\
2000\end{array}$ & ASB issues FRS 17 & $\begin{array}{l}\text { Proposals implemented: effective } \\
2003\end{array}$ \\
\hline 5 July 2002 & $\begin{array}{l}\text { ASB delays implementation of } \\
\text { FRS } 17\end{array}$ & $\begin{array}{l}\text { ASB postpones the } \\
\text { implementation of FRS } 17 \text { until } \\
2005 \text { for re-issue of IAS } 19\end{array}$ \\
\hline 1 Jan 2005 & SB implements FRS17 & FRS17 takes effect from this date. \\
\hline
\end{tabular}

Table Notes: Refer to Statements of Standard Accounting Practice 24, Statements of Financial Accounting Standard 87, International Accounting Standard 19 and Financial Rep orting Standard 17. 
Table II

Differences in Discounting Assumptions Between Accounting UK, US and International Pension Cost Accounting Standards

\begin{tabular}{|l|l|l|l|l|}
\hline Feature & SSAP 24 & SFAS 87 & $\underline{\text { IAS 19 }}$ & FRS 17 \\
\hline Origin of GAAP & UK & US & International & UK \\
\hline $\begin{array}{l}\text { Discount rate: } \\
\text { Pension assets }\end{array}$ & $\begin{array}{l}\text { Actuarial } \\
\text { (long term) } \\
\text { value }\end{array}$ & $\begin{array}{l}\text { Market value } \\
\text { (smoothed) }\end{array}$ & Market value & Market value \\
\hline $\begin{array}{l}\text { Discount rate: } \\
\text { pension liabilities }\end{array}$ & $\begin{array}{l}\text { Long-term } \\
\text { rate of return } \\
\text { expected on } \\
\text { actual asset } \\
\text { portfolio }\end{array}$ & $\begin{array}{l}\text { Prime } \\
\text { corp orate bond } \\
\text { return }\end{array}$ & $\begin{array}{l}\text { Prime } \\
\text { corp orate bond } \\
\text { return }\end{array}$ & $\begin{array}{l}\text { Gilt bond } \\
\text { return }\end{array}$ \\
\hline $\begin{array}{l}\text { Treatment of } \\
\text { gains or losses }\end{array}$ & Spread & $\begin{array}{l}\text { Spread outside } \\
\text { corridor }\end{array}$ & $\begin{array}{l}\text { Spread outside } \\
\text { corridor }\end{array}$ & $\begin{array}{l}\text { Immediate } \\
\text { write-off }\end{array}$ \\
\hline $\begin{array}{l}\text { Actuarial } \\
\text { valuation } \\
\text { methodology }\end{array}$ & $\begin{array}{l}\text { Actuarial } \\
\text { judgment } \\
\text { using 'best }\end{array}$ & $\begin{array}{l}\text { Interest on past } \\
\text { service } \\
\text { liabilities plus } \\
\text { return on } \\
\text { assets }\end{array}$ & $\begin{array}{l}\text { Interest on past } \\
\text { service } \\
\text { liabilities plus } \\
\text { return on } \\
\text { assets }\end{array}$ & $\begin{array}{l}\text { Interest on } \\
\text { past service } \\
\text { liabilities } \\
\text { plus return on } \\
\text { assets }\end{array}$ \\
\hline $\begin{array}{l}\text { Assumed pension } \\
\text { liabilities }\end{array}$ & Any & ABO (PBO) & ABO & ABO \\
\hline $\begin{array}{l}\text { Valuation } \\
\text { frequency }\end{array}$ & Triennial & Annual & Annual & Annual \\
\hline
\end{tabular}

Table Notes: Refer to Statements of Standard Accounting Practice 24, Statements of Financial Accounting Standard 87, International Accounting Standard 19 and Financial Rep orting Standard 17. 


\section{Table III \\ S ample Details}

\begin{tabular}{|c|c|c|c|}
\hline Industry & $\begin{array}{l}\text { Switch } \\
\text { Firms }\end{array}$ & $\begin{array}{l}\text { Low Pension Expense } \\
\text { Firms }\end{array}$ & $\begin{array}{l}\text { Non-switch } \\
\text { Firms }\end{array}$ \\
\hline Building and Construction & McAlpine & Bett Brothers & Mowlem \\
\hline Brewing & Guinness / Diageo & Allied Domecq & Whitbread \\
\hline Engineering/A gricultural & Hall En gin eering & Slough & Carr's Milling \\
\hline Engineering & Molins & Haynes & Ricardo \\
\hline Financial Services (banking) & NationalWestminster & Bank of Scotland & HSBC Holdings \\
\hline Financial Services (retail) & Hogg Robinson & Britannic & Legal \& General \\
\hline Financial Services (brokerage) & James Finlay & Halifax & Provident Financial \\
\hline Food M anufacturing & Assoc. British Foods & Aggregate & Bernard Matthews \\
\hline Industrial Instruments & Norcos & United Business & Smiths Industries \\
\hline Medical and Chemical & Imp erial Chemical & Chemex & Smith \& Nephew \\
\hline Packaging and Distribution & Waddington & Independent & James Latham \\
\hline Publishing and Advertising & News International & Johnston & Pearson \\
\hline Manufacturing & Bunzl & Sinclair & British Vita \\
\hline Manufacturing & Cadbury Schweppes & Rentokil & General Electric \\
\hline Manufacturing & Garton Engineering & Charter & Relyon \\
\hline Manufacturing & Pilkington & DeLaRue & Williams Holdings \\
\hline Manufacturing & Airsprung Furniture & Homestyle & Blue Circle \\
\hline Pharmaceutical & Smithkline Beecham & Glaxo & Astra-Zeneca \\
\hline Leisure & Granada & Thomson & Rank Group \\
\hline Retail - food & Boots & Swan Hill & Safeway \\
\hline Retail - beverages & Greenalls & Malcolm & Eldridge Pope \\
\hline Retail - household & Dixons Group & Grampian & Silentnight \\
\hline Retail - clothing & House of Fraser & James Beattie & Kingfisher \\
\hline Retail - diversified & Storehouse & GUS & Sainsbury \\
\hline Resources and minerals & BP-Amoco & BNB Resources & British Steel \\
\hline Services & Securicor & Brooke & BAA \\
\hline Technology & Johnson Matthey & Reuters & FI Group \\
\hline Telecommunications & BT & Carlton & Vodafone-Airtouch \\
\hline Travel & British Airways & First choice & Stagecoach \\
\hline Utilities - reticulation & Scottish Power & United Utilities & Severn Trent \\
\hline Utilities - generation & Powergen & Carbo & Ocean Group \\
\hline
\end{tabular}

Table Notes: The sample is selected using an industry-matched pair sample procedure, following Ghicas (1990). Industry segments were selected based on those reported in the Financial Times. Firms considered for inclusion in the sample met the following criteria: (1) sponsored defined benefit pension funds ex ceeding $£ 10$ million as reported in the industry publication Pension Funds and Their Advisers; (2) were listed in the FTSE 500 for the last ten years; (3) had complete financial and actuarial data available on Datastream from 1994-1999. Firms were classified as using 'market-based' discount rates if their disclosed actuarial pension asset and/or liability assumptions were updated more frequently than that required by actuarial requi rements (i.e. more than once every three years). An industry-matched pair firm was then randomly selected which did not update its actuarial assumptions by more than once every three years. A third industry matched pair firm was selected which did not record a pension expense exceeding 5\% of its net sales for the period 1994-1999. 
Table IV

Calendar Dates for Three Subperiods

Surrounding the Release of AS B's Pension Cost Proposals

(Financial Reporting Exposure Draft 20 'FRED 20') on 30 November 1999

\begin{tabular}{|c|c|c|c|}
\hline & Subperiod & Dates & $\begin{array}{l}\text { No. of } \\
\text { Trading } \\
\text { Days }\end{array}$ \\
\hline 1. & $\begin{array}{l}\text { The "Pre-Announcement" period used for } \\
\text { estimating the "Market Model" parameters for } \\
\text { each firm }\end{array}$ & $\begin{array}{l}14 \text { April } 1999 \text { - } \\
1 \text { Sep tember } 1999\end{array}$ & 100 \\
\hline & The "Announcement" p eriod & $\begin{array}{l}2 \text { September } 1999 \text { - } \\
30 \text { November } 1999\end{array}$ & 45 \\
\hline & The "Post-Announcement" period & $\begin{array}{l}3 \text { December } 1999- \\
17 \text { December } 1999\end{array}$ & $\underline{10}$ \\
\hline
\end{tabular}




\section{Table V}

\section{Univariate Tests and Descriptive $S$ tatistics}

\section{Switch Firms $(n=31)$ and Industry-Matched Non-switch $(n=31)$ Firms}

The sample comprises $62 \mathrm{UK}$ firms that switched to a market-based actuarial valuation of their pension assets and liabilities during 1995-1998 and an industry matched pair sample of 31 UK firms that either did or did not switch during this period. Data are pooled for the four years between January 1995 and December 1998, and between January 2000 and December 2003.

\begin{tabular}{|c|c|c|c|c|c|c|c|}
\hline \multirow[t]{2}{*}{ Variables } & \multirow[t]{2}{*}{ Period } & \multicolumn{2}{|c|}{$\begin{array}{c}\text { Switch Firms } \\
\text { (1) }\end{array}$} & \multicolumn{2}{|c|}{$\begin{array}{c}\text { Non-switch firms } \\
(0)\end{array}$} & \multirow[t]{2}{*}{$\begin{array}{l}\text { Matched- } \\
\text { Pairs t- } \\
\text { test }\end{array}$} & \multirow[t]{2}{*}{$\begin{array}{c}\text { Wilcoxon } \\
\text { Pairs } \\
\text { test }\end{array}$} \\
\hline & & Mean & Std & Mean & Std & & \\
\hline$L T D / V_{i t}$ & 1995-1998 & $\begin{array}{l}1278 \\
1765\end{array}$ & $\begin{array}{l}\text { Dev. } \\
2445 \\
6162\end{array}$ & $\begin{array}{r}353 \\
1012\end{array}$ & $\begin{array}{r}\text { Dev. } \\
431 \\
2725\end{array}$ & $4.141^{\mathrm{a}}$ & $\begin{array}{r}1.395 \\
36579\end{array}$ \\
\hline \multirow[t]{2}{*}{$P L / V_{i t}$} & $1995-1998$ & 1546 & 3606 & $\begin{array}{r}1012 \\
553\end{array}$ & 1030 & $2.968^{\mathrm{a}}$ & $2.706^{\mathrm{a}}$ \\
\hline & $2000-2003$ & 1695 & 4242 & 769 & 1707 & $4.463 \mathrm{a}$ & $4.419 \mathrm{a}$ \\
\hline \multirow[t]{2}{*}{$P L^{M} / V_{i t}$} & $1995-1998$ & 1527 & 3545 & 767 & 1372 & $3.775^{\mathrm{a}}$ & $2.768^{\mathrm{a}}$ \\
\hline & $2000-2003$ & 1783 & 4464 & 1138 & 5584 & $2.416 \mathrm{a}$ & $-4.899 a$ \\
\hline \multirow[t]{2}{*}{$P A / V_{i t}$} & 19951998 & 1666 & 3691 & 553 & 1031 & $3.525^{\mathrm{a}}$ & $-2.571^{\mathrm{a}}$ \\
\hline & $2000-2003$ & 1782 & 4183 & 920 & 2098 & $4.668 \mathrm{a}$ & $-4.349 a$ \\
\hline \multirow[t]{2}{*}{$P A^{M} / V_{i t}$} & 1995-1998 & 1764 & 3776 & 867 & 1547 & $2.627^{\mathrm{a}}$ & $-2.940^{\mathrm{a}}$ \\
\hline & $2000-2003$ & 1885 & 4306 & 949 & 2222 & $4.968 \mathrm{a}$ & -4.816 \\
\hline \multirow[t]{2}{*}{$N I / V_{i t}$} & 1995-1998 & 637 & 990 & 261 & 286 & $4.326^{\mathrm{a}}$ & $-2.035^{\mathrm{b}}$ \\
\hline & $2000-2003$ & 542 & 1139 & 323 & 1693 & $4.039 \mathrm{a}$ & $-3.794 a$ \\
\hline \multirow[t]{2}{*}{$P U T_{1} / V_{i t}$} & 1995-1998 & 0.080 & 0.134 & 0.088 & 0.157 & 0.161 & -0.101 \\
\hline & $2000-2003$ & 0.10 & 0.182 & 0.120 & 0.470 & 1.109 & -1.018 \\
\hline \multirow[t]{2}{*}{$C A L L / V_{i t}$} & 1995-1998 & 0.060 & 0.296 & 0.081 & 0.153 & 0.809 & -0.801 \\
\hline & $2000-2003$ & 0.08 & 0.261 & 0.100 & 0.433 & 0.852 & -0.898 \\
\hline
\end{tabular}

$p_{i t}=$ cumulative monthly return on firm's stock price (adjusted for dividend and firm recapitalisation).

$L T D / V_{\text {it }}=$ total long term debt, divided by market value of equity.

$P L / V_{\text {it }}=$ total pension liabilities discounted by the firms' chosen expected rat e of return on pension assets, divided by market value of equity.

$P L^{M} / V_{i t}=$ total pension liabilities discounted by the rate applicable for high-grade 1 year UK corporate bonds, divided by market value of equity.

$P A / V_{i t}=$ total actuarial funded pension assets, divided by the market value of equity.

$P A^{M} / V_{i t}=$ Total market value of pension assets disclosed by footnote by employer sponsor for equival ent year, divided by market value of equity.

$N I / \mathrm{V}_{\text {it }}=$ Annual net income of pension fund for year before pension and interest expense $\left(\mathrm{I}_{\mathrm{t}}-\mathrm{I}_{\mathrm{t}-1}\right) / \mathrm{I}_{\mathrm{t}-1}$, divided by the market value of equity.

$\mathrm{PUT}^{1} / \mathrm{V}_{\text {it }}=$ put option value to terminate pensions assuming an interest rate equal to firm i's chosen expect ed return on pension assets, divided by market value of equity

$\mathrm{CALL} / \mathrm{V}_{\mathrm{it}}=$ employees' option value to improve pension benefits above the minimum termination values, assuming an interest rate equal to high-grade 1 year corporate bonds, divided by market value of equity

${ }^{a}$ Significant at the 0.01 level of significance for one-tail test

${ }^{\mathrm{b}}$ Significant at the 0.05 level of significance for one-tail test

${ }^{\mathrm{c}}$ Significant at the 0.10 level of significance for one-tail test 
Table VI

Daily Mean Market-Adjusted Abnormal Returns (AR) an d Cumulative Sum of the Daily Mean Abnormal Returns (CAR)

For the Issue of FRS 17 (30 November, 1999)

\begin{tabular}{|c|c|c|c|c|c|c|}
\hline \multirow[b]{2}{*}{ Day } & \multicolumn{2}{|c|}{ Market Valuation Group } & \multicolumn{2}{|c|}{ Low Pension Expense Group } & \multicolumn{2}{|c|}{ Non Market Valuation Group } \\
\hline & $\mathrm{AR}$ & CAR & $\mathrm{AR}$ & CAR & $\mathrm{AR}$ & CAR \\
\hline-45 & 0.00455 & 0.00455 & $* *-0.01273$ & -0.01273 & 0.00230 & 0.00230 \\
\hline-44 & 0.00050 & 0.00505 & -0.00661 & -0.01934 & -0.00404 & -0.00173 \\
\hline-43 & -0.00046 & 0.00459 & 0.00391 & -0.01543 & -0.00208 & -0.00381 \\
\hline-42 & -0.00135 & 0.00325 & -0.00610 & -0.02153 & -0.00658 & -0.01039 \\
\hline-41 & -0.00145 & 0.00179 & -0.00555 & -0.02707 & 0.00036 & -0.01075 \\
\hline-40 & 0.00012 & 0.00191 & 0.00298 & -0.02410 & 0.00092 & -0.00983 \\
\hline-39 & -0.01100 & -0.00909 & -0.00628 & -0.03037 & $*_{-0.01103}$ & -0.02086 \\
\hline-38 & -0.00417 & -0.01326 & -0.00333 & -0.03371 & 0.00076 & -0.02010 \\
\hline-37 & $*_{-0.00896}$ & -0.02222 & $* *-0.01253$ & -0.04624 & -0.00474 & -0.02484 \\
\hline-36 & -0.00794 & -0.03016 & $*_{-0.01039}$ & -0.05663 & -0.00128 & -0.02612 \\
\hline-35 & -0.00224 & -0.03240 & -0.00773 & -0.06436 & -0.00762 & -0.03374 \\
\hline-34 & 0.00435 & -0.02805 & 0.00216 & -0.06220 & 0.00333 & -0.03041 \\
\hline-33 & -0.00608 & -0.03413 & 0.00293 & -0.05927 & -0.00368 & -0.03409 \\
\hline-32 & 0.00402 & -0.03011 & $* *-0.01626$ & -0.07553 & -0.00155 & -0.03564 \\
\hline-31 & -0.00425 & -0.03436 & 0.00067 & -0.07486 & 0.00139 & -0.03425 \\
\hline-30 & -0.00182 & -0.03618 & -0.00097 & -0.07583 & -0.00177 & -0.03602 \\
\hline-29 & 0.00236 & -0.03382 & -0.00723 & -0.08306 & 0.00102 & -0.03500 \\
\hline-28 & 0.00383 & -0.02999 & 0.00866 & -0.07440 & -0.00051 & -0.03551 \\
\hline-27 & 0.00474 & -0.02526 & 0.00206 & -0.07235 & 0.00055 & -0.03496 \\
\hline-26 & -0.00359 & -0.02885 & -0.00774 & -0.08009 & 0.00357 & -0.03138 \\
\hline-25 & $* 0.01095$ & -0.01790 & -0.00102 & -0.08111 & 0.00372 & -0.02767 \\
\hline-24 & 0.00445 & -0.01345 & -0.00204 & -0.08315 & 0.00261 & -0.02505 \\
\hline-23 & $* * 0.01400$ & 0.00055 & 0.00811 & -0.07504 & 0.00120 & -0.02385 \\
\hline-22 & $* 0.01009$ & 0.01064 & 0.00356 & -0.07148 & 0.00789 & -0.01596 \\
\hline-21 & 0.00085 & 0.01149 & 0.00037 & -0.07111 & 0.00727 & -0.00896 \\
\hline-20 & 0.00153 & 0.01302 & -0.00207 & -0.07317 & *0.01223 & 0.00353 \\
\hline-19 & 0.00649 & 0.01951 & 0.00316 & -0.07002 & 0.00323 & 0.00677 \\
\hline-18 & -0.00470 & 0.01482 & 0.00061 & -0.06941 & -0.00178 & 0.00499 \\
\hline-17 & -0.00340 & 0.01142 & 0.00852 & -0.06089 & -0.00655 & -0.00156 \\
\hline-16 & -0.00537 & 0.00604 & 0.00874 & -0.05215 & -0.00602 & -0.00759 \\
\hline-15 & 0.00180 & 0.00785 & 0.00616 & -0.04599 & 0.00075 & -0.00683 \\
\hline-14 & -0.00215 & 0.00569 & $* *-0.01491$ & -0.06090 & -0.00682 & -0.01366 \\
\hline-13 & 0.00948 & 0.01518 & *0.01302 & -0.04789 & 0.00217 & -0.01148 \\
\hline-12 & 0.00026 & 0.01544 & 0.00044 & -0.04745 & -0.00129 & -0.01278 \\
\hline-11 & -0.00676 & 0.00868 & -0.00248 & -0.04993 & 0.00135 & -0.01143 \\
\hline-10 & 0.00115 & 0.00983 & 0.00211 & -0.04782 & $* 0.00976$ & -0.00168 \\
\hline-9 & -0.00482 & 0.00501 & -0.00812 & -0.05594 & -0.00544 & -0.00712 \\
\hline-8 & 0.00581 & 0.01082 & 0.00866 & -0.04728 & -0.00151 & -0.00863 \\
\hline-7 & 0.00157 & 0.01293 & $*_{-0.01059}$ & -0.05787 & 0.00383 & -0.00480 \\
\hline-6 & 0.00303 & 0.01542 & 0.00141 & -0.05646 & 0.00031 & -0.00449 \\
\hline-5 & 0.00019 & 0.01561 & -0.00116 & -0.05762 & -0.00059 & -0.00508 \\
\hline-4 & 0.00098 & 0.01659 & 0.01072 & -0.04690 & 0.00759 & 0.00251 \\
\hline-3 & -0.00222 & 0.01436 & -0.00611 & -0.05301 & 0.00140 & 0.00391 \\
\hline-2 & -0.00048 & 0.01388 & -0.00792 & -0.06093 & -0.00167 & 0.00224 \\
\hline-1 & 0.00132 & 0.01520 & -0.00228 & -0.06321 & -0.00298 & -0.00074 \\
\hline 0 & $* 0.00968$ & 0.02488 & -0.00110 & -0.06431 & 0.00824 & 0.00750 \\
\hline 1 & -0.00176 & 0.02312 & $*_{-0.01011}$ & -0.07442 & -0.00050 & 0.00700 \\
\hline 2 & -0.00010 & 0.02302 & 0.00814 & -0.06629 & -0.02979 & -0.02279 \\
\hline 3 & -0.00226 & 0.02077 & 0.00367 & -0.06262 & 0.00331 & -0.01948 \\
\hline 4 & -0.00786 & 0.01291 & $*_{-0.01058}$ & -0.07320 & -0.00105 & -0.02053 \\
\hline 5 & -0.00059 & 0.01232 & -0.00367 & -0.07687 & -0.00214 & -0.02266 \\
\hline 6 & -0.00675 & 0.00557 & -0.00196 & -0.07883 & $* *-0.03286$ & -0.05552 \\
\hline 7 & 0.00090 & 0.00646 & -0.00180 & -0.08063 & -0.02720 & -0.08272 \\
\hline 8 & -0.00468 & 0.00183 & 0.00676 & -0.07387 & 0.00245 & -0.08027 \\
\hline 9 & $*_{-0.00955}$ & -0.00772 & -0.00624 & -0.08011 & -0.00092 & -0.08119 \\
\hline
\end{tabular}


Table VII

Mean Abnormal Returns in Immediate Pre- and Post-Announcement Periods FRS 17 (Issued 30 November 1999)

\begin{tabular}{|cccc|}
\hline Pre-Announcement Period: & $\begin{array}{c}\text { Market } \\
\text { valuation } \\
\text { group }\end{array}$ & $\begin{array}{c}\text { Low pension } \\
\text { exp ense } \\
\text { group }\end{array}$ & $\begin{array}{c}\text { Non-Market } \\
\text { valuation } \\
\text { group }\end{array}$ \\
\hline $\mathrm{t}=-42$ through $\mathrm{t}=-38$ & -0.0035 & -0.0031 & -0.0031 \\
$\mathrm{t}=-36$ through $\mathrm{t}=-32$ & $(-1.743)$ & $(-1.095)$ & $(-1.352)$ \\
& -0.0007 & -0.0054 & -0.0015 \\
$\mathrm{t}=-5$ through $\mathrm{t}=-1$ & $(-0.354)$ & $(-0.917)$ & $(-0.929)$ \\
& 0.0005 & -0.0026 & 0.0010 \\
Post-Announcement & $*(\mathbf{1 . 9 8 5 )}$ & $(-0.389)$ & $(0.482)$ \\
Period: & & & \\
$\mathrm{t}=1$ through $\mathrm{t}=5$ & -0.0029 & -0.0018 & -0.0054 \\
$\mathrm{t}=1$ through $\mathrm{t}=10$ & $* *(-3.449)$ & $(0.291)$ & $(-0.335)$ \\
& -0.0898 & -0.1018 & -0.1033 \\
Various Intervals: & $(-0.014)$ & $(-0.012)$ & $(-0.014)$ \\
$\mathrm{t}=-30$ through $\mathrm{t}=-1$ & 0.0016 & 0.0004 & 0.0011 \\
$\mathrm{t}=-20$ through $\mathrm{t}=-1$ & $(0.667)$ & $(0.086)$ & $(0.534)$ \\
$\mathrm{t}=-10$ through $\mathrm{t}=-1$ & 0.0002 & 0.0004 & 0.0004 \\
& $(0.123)$ & $(0.079)$ & $(0.170)$ \\
& 0.0006 & -0.0013 & 0.0011 \\
& $(0.917)$ & $(-0.296)$ & $(0.548)$ \\
\hline
\end{tabular}

Table Notes: The z statistics of equation (6) are in parentheses.

$* *=$ Significant at $1 \%$ level.

$*=$ Significant at $5 \%$ level.

$+=$ Significant at $10 \%$ level. 
Table VIII

Regressions of Announcement Period Returns on Abnormal Returns ( $t$-statistics and ( $p$-values) under coefficient estimates)

$\overline{\text { Return }=\alpha_{0}+\alpha_{1} \mathrm{AR}_{\mathrm{Mkt}} * \mathrm{POST}_{\mathrm{ANN}}+\alpha_{2} \mathrm{AR}_{\mathrm{LPE}} * \mathrm{POST}_{\mathrm{ANN}}+\alpha_{3} \mathrm{AR}_{\mathrm{NMk}} * \mathrm{POST}_{\mathrm{ANN}}+}$ $\varepsilon$

\begin{tabular}{|c|c|c|c|c|c|c|}
\hline Model & $\overline{\mathrm{N}}$ & Intercept & $\begin{array}{c}\mathrm{AR}_{\mathrm{Mkt}}{ }^{*} \\
\mathrm{POST}_{\mathrm{ANN}}\end{array}$ & $\begin{array}{c}\mathrm{AR}_{\mathrm{LPE}}{ }^{*} \\
\mathrm{POST}_{\mathrm{ANN}}\end{array}$ & $\begin{array}{c}\mathrm{AR}_{\mathrm{NMk}}{ }^{*} \\
\mathrm{POST}_{\mathrm{ANN}}\end{array}$ & $\overline{A d j} R^{2}$ \\
\hline \multirow[t]{3}{*}{1} & 1023 & 0.004 & 0.772 & - &  & $\overline{0.040}$ \\
\hline & & 0.48 & 6.517 & & & \\
\hline & & $(0.630)$ & $\overline{(0.001)}$ & & & \\
\hline \multirow[t]{3}{*}{2} & 1023 & 0.006 & 0.772 & - & 0.002 & 0.042 \\
\hline & & 0.547 & 6.529 & & 2.026 & \\
\hline & & $(0.585)$ & $(0.001)$ & & $(0.043)$ & \\
\hline \multirow[t]{3}{*}{3} & 1023 & 0.075 & 0.771 & 0.001 & 0.002 & 0.041 \\
\hline & & 0.319 & 6.519 & 0.474 & 2.018 & \\
\hline & & $(0.750)$ & $(0.001)$ & $(0.636)$ & $(0.048)$ & \\
\hline
\end{tabular}

$\mathrm{H}_{0}: \mathrm{AR}_{\mathrm{Mkt}} * \mathrm{POST}_{\mathrm{ANN}}=\mathrm{AR}_{\mathrm{NMkt}} * \mathrm{POST}_{\mathrm{ANN}}$,

F-statistic $=23.352, \mathrm{p}$-value $=0.0001$

Table Notes: This table presents regressions of announcement period raw stock returns (Return) on abnormal returns calculated relative to $A R_{M k t}\left(P_{L P E}\right)$ and $A R_{N M k t}$ $\left(\mathrm{PE}_{\mathrm{LPE}}\right)$. The announcement period is defined as the period beginning five days after the ASB's issue of the pension cost accounting exposure draft FRED 20 and ending 5 days, where the announcement date is defined as 30 November 1999, i.e. the issue date of FRED 20. 


\section{Table IX}

\section{Effect of Unexpected Interest Rate Changes on Monthly S tock Returns}

This table reports the pooled regression an alysis for effect of unexpect ed interest rate changes, mark et return and earnings coefficients on monthly stock returns (equation 3). The t-ratio is reported together with the relevant coefficient. The pre announcement period is from January 1995 to December 1998 and the post announcement period is from January 2000 to December 2003. Unexpected rates are defined in terms of unexpected changes, relative to the assumed pension plan liability discount rate, of the prime corporate bond rate. The samples are those described in Table 2.

$$
\begin{aligned}
r_{i t}=\alpha_{i}+ & \gamma_{0} \Delta R_{t}+\gamma_{1} \Delta R_{t} F P L / V_{i t}+\gamma_{2} \Delta R_{t} L T D / V_{i t}+\gamma_{3} \Delta R_{t} P L^{A-M} / V_{i t} \\
& +\gamma_{4} \Delta R_{t} F P A / V_{i t}+\gamma_{5} \Delta R_{t} P A^{A-M} / V_{i t}+\gamma_{6} P U T / V_{i t}++\gamma_{7} C A L L / V_{i t}+\varepsilon_{i t}
\end{aligned}
$$

Panel A: Pre-Announcement period (January 1995 to December 1998)

\begin{tabular}{|c|c|}
\hline \multicolumn{2}{|c|}{ Non-Switch Firms } \\
\hline Coefficient & t-statistic \\
\hline 10.167 & 1.215 \\
\hline 3.085 & 0.973 \\
\hline-0.004 & -0.283 \\
\hline 0.004 & 0.244 \\
\hline-0.006 & -0.147 \\
\hline 0.003 & 0.567 \\
\hline 0.003 & 1.437 \\
\hline 0.024 & $1.738^{\mathrm{c}}$ \\
\hline-81.335 & $-4.291^{\mathrm{a}}$ \\
\hline
\end{tabular}

\begin{tabular}{lccr}
\multicolumn{1}{c}{ Firm Sample } & sign & Coefficient & Switch Firms \\
& & 3.068 & 0.460 \\
Intercept & $?$ & 3.341 & 1.230 \\
$\Delta R_{i t}$ & + & -0.006 & -0.191 \\
$\Delta R_{i t} * P L / V_{i t}$ & - & 0.004 & 0.134 \\
$\Delta R_{i t} * P A / V_{i t}$ & + & -0.006 & -0.947 \\
$\Delta R_{i t} * L T D / V_{i t}$ & - & 0.016 & 0.869 \\
$\Delta R_{i t} * P L^{A-M} / V_{i t}$ & + & 0.002 & 0.816 \\
$\Delta R_{i t} * P A^{A-M} / V_{i t}$ & + & 0.009 & $2.417^{\mathrm{a}}$ \\
$N I / V_{i t}$ & + & & $-3.387^{\mathrm{a}}$ \\
$P U T_{i t}$ & - & -67.747 & \\
$C A L L_{i t}$ & - & 0.118, Overall Model $\mathrm{F}=2.834^{\mathrm{a}}$
\end{tabular}

0.206 , Overall Model F=3.294

Panel B: Post announcement period (January 2000 to December 2003) Switchers




Figure 1

Comparison of Mean Cumulative Abnormal Returns by event day

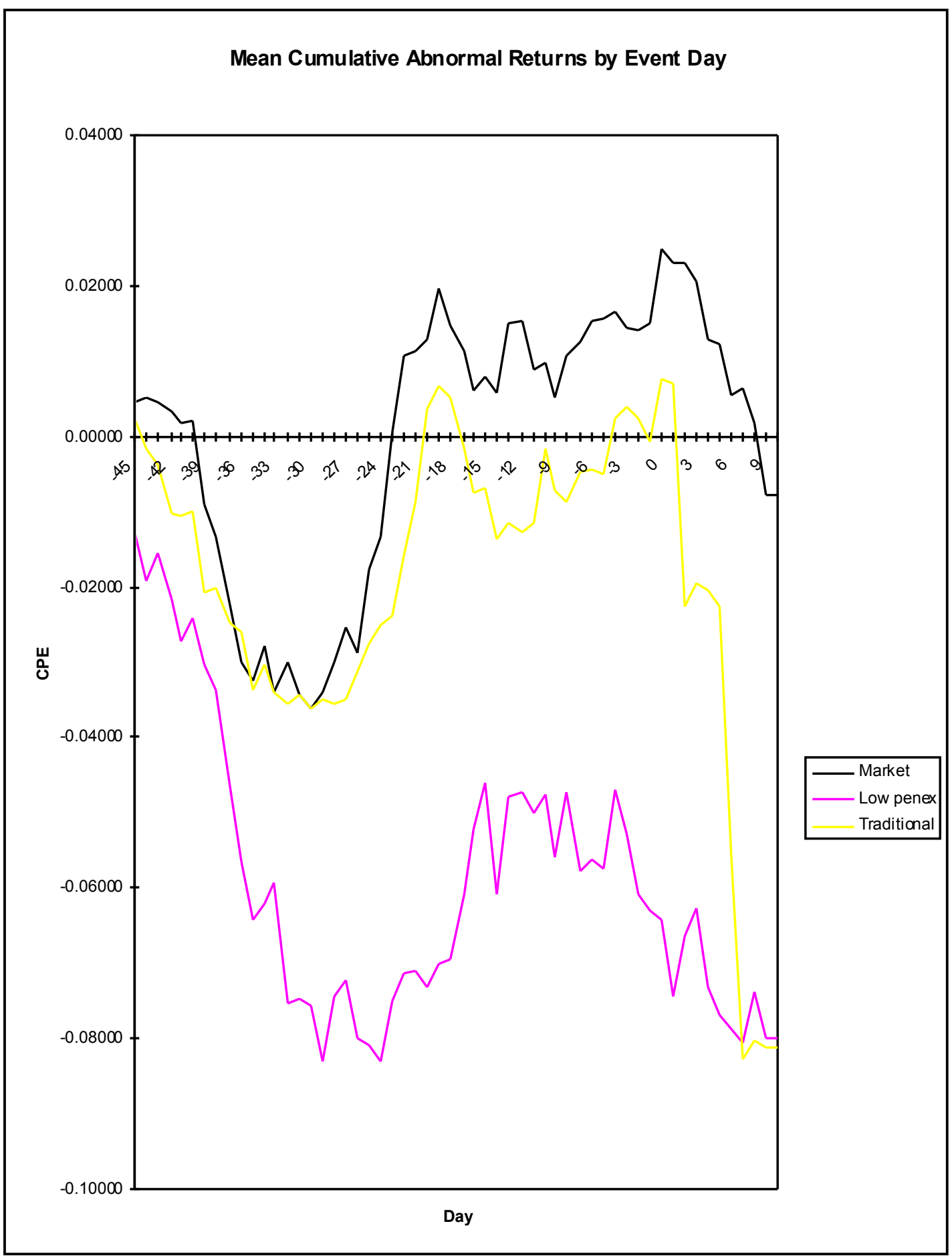


